\title{
Cannibalism by female Calanus finmarchicus on naupliar stages
}

\author{
Sünnje L. Basedow*, Kurt S. Tande \\ Norwegian College of Fishery Science, University of Tromsø, Breivika, 9037 Tromsø, Norway
}

\begin{abstract}
Cannibalism has been assumed to strongly affect population dynamics of the calanoid copepod Calanus spp. during the pre-bloom phase. We hypothesised that Calanus finmarchicus females cannibalise on nauplii until there is enough phytoplankton available to fulfil their energy demands. We tested this experimentally by exposing females to different concentrations of algae Thalassiosira weissflogii (0.08 to $22.58 \mu \mathrm{g}$ chlorophyll $\mathrm{a} \mathrm{l}^{-1}$ ) and nauplii (stages NI and NII, 0 to

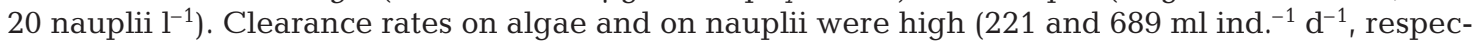
tively), but were independent of algal concentration. Females ingested naupliar carbon at a higher proportion than was available, even when naupliar carbon accounted for $<5 \%$ of the totally available carbon. Predation rates on nauplii increased linearly and significantly $(p<0.001)$ with increasing nauplii abundance. Compared with literature values, predation rates were considerably higher (up to 10 nauplii ind. ${ }^{-1} \mathrm{~d}^{-1}$ ) than predation rates of the sibling species C. helgolandicus and C. pacificus on their nauplii, and also higher than predation rates of the omnivorous copepod Metridia lucens on Calanus sp. nauplii. Based on our data, we estimated that as much as $20 \% \mathrm{~d}^{-1}$ of the nauplii population may be preyed on by adult females. Thus, during the pre-bloom period when abundance of nauplii is small and that of females is large, cannibalism may prevent recruitment to the G1 population.
\end{abstract}

KEY WORDS: Calanus $\cdot$ Switching $\cdot$ Feeding $\cdot$ Food $\cdot$ Prey $\cdot$ Preference Resale or republication not permitted without written consent of the publisher

\section{INTRODUCTION}

The calanoid copepod Calanus finmarchicus dominates the meso-zooplankton biomass in the North Atlantic Ocean (Planque \& Batten 2000). Because of its enormous abundance it is the main food source for many commercially important fish species like Atlantic herring Clupea harengus and larval Atlantic cod Gadus morhua (Dalpadado et al. 2000, Gaard \& Reinert 2002, Gislason \& Astthorsson 2002). C. finmarchicus itself exerts intense grazing pressure on phytoplankton blooms (Harvey 1936, Longhurst 1976, Dale et al. 1999) and has long been viewed as a typical example of a herbivore filter-feeder (e.g. Marshall \& Orr 1955). During the last decade, however, it has become clear that the diet of $C$. finmarchicus is more complex and consists not only of phytoplankton but also, at least periodically, of micro-zooplankton (Ohman \& Runge 1994, Levinsen et al. 2000).
Cannibalism is widespread in the animal kingdom (Lorenz 1966, Wilson 1975), especially during periods of food scarcity (Fox 1975, Polis 1981), and has been reported among calanoid copepods (reviewed by Bonnet et al. 2004). Cannibalism by Calanus pacificus and C. helgolandicus on eggs and nauplii (Landry 1980, Kang \& Poulet 2000, Bonnet et al. 2004) suggests that this phenomenon may also occur in the closely related C. finmarchicus. Eggs and nauplii may be an attractive food source for adults during periods of food shortage. For broadcast spawners like $C$. finmarchicus, the risk of ingesting their own offspring is minimal and cannibalism may be a rewarding strategy to compensate for lack of algal food.

Besides being of nutritional value for adults, cannibalism may significantly affect mortality rates of the offspring population (Landry 1978, 1980, Ohman \& Hirche 2001, Bonnet et al. 2004) and seriously affect recruitment. Interannual variability in the population 
size of Calanus finmarchicus is high, but the cause of the observed variance is still poorly understood. Recruitment of nauplii to copepodites is a key factor in the population dynamics of $C$. finmarchicus. Cannibalism by adults on their offspring may thus, in addition to variation in algal biomass and composition (Irigoien et al. 2003), help to explain the observed high interannual variance in the population size of $C$. finmarchicus.

In the oceanic environment, large numbers of female Calanus finmarchicus spawn before the spring algal bloom (Niehoff et al. 1999), leading to an annual recurrent situation of low abundance of algae and high abundance of adults and their offspring. Cannibalism has previously been assumed to strongly impact population dynamics of Calanus spp. during the pre-bloom period (Ohman \& Hirche 2001, Eiane et al. 2002, Bonnet et al. 2004). Following this, we hypothesised that $C$. finmarchicus females will cannibalise on nauplii until algal concentrations are high enough to fulfil their energy demands, after which they switch to being solely herbivorous. In order to test this experimentally, we offered $C$. finmarchicus females algae and nauplii at different concentrations.

\section{MATERIALS AND METHODS}

Collection and maintenance of copepods. Copepods were collected with a plankton trawl in Grøtsund $\left(69^{\circ} 48^{\prime} \mathrm{N}, 19^{\circ} 20^{\prime} \mathrm{E}\right)$ northeast of Tromsø, Norway, in spring 2004 and spring 2005. The plankton trawl was a $2 \times 2 \mathrm{~m}$ net with $500 \mu \mathrm{m}$ mesh and a $60 \mathrm{lnon}$-filtering cod end to capture live animals. The net was trawled between 0.5 and $1 \mathrm{~h}$ at low ship speed (ca. $1 \mathrm{knot}$ ) in the upper $60 \mathrm{~m}$. Once collected, animals were gently transferred from the cod end into $60 \mathrm{l}$ plastic containers half-filled with seawater. The containers were protected from sunlight by a black plastic sack and transported (ca. $1.5 \mathrm{~h})$ to the cooling room $\left(6^{\circ} \mathrm{C}\right)$ at the institute. On arrival, copepods were transferred into $60 \mathrm{l}$ false-bottom (500 $\mu \mathrm{m}$ mesh) containers stacked into another $60 \mathrm{l}$ container. Every $24 \mathrm{~h}$ the false-bottom container was set into another container filled with fresh seawater, filtered through $1 \mu \mathrm{m}$, and fresh algae suspension (ca. $10 \mu \mathrm{g} \mathrm{l}^{-1}$ Thalassiosira weissflogii during spring 2004 and different diatoms during spring 2005). During this procedure, females were exposed to air for ca. $1 \mathrm{~s}$. The eggs that were produced over $24 \mathrm{~h}$ were siphoned from the bottom into a $10 \mathrm{l}$ beaker for hatching. Copepods were acclimated for at least $48 \mathrm{~h}$ prior to the experiment. Then, $24 \mathrm{~h}$ before the experiment, approximately 100 females were transferred from the containers into $10 \mathrm{l}$ beakers filled with filtered seawater to increase their hunger state and adjust the stomach contents to an equal level.
Phytoplankton cultures. The small non-chain-forming diatom Thalassiosira weissflogii (equivalent spherical diameter $=$ ca. $12 \mu \mathrm{m}$ ), which is ingested readily by Calanus finmarchicus (Reigstad et al. 2005), was used for the experiments. Cultures were grown in $10 \mathrm{l} \mathrm{Nal-}$ gene bottles filled with filtered $(1 \mu \mathrm{m})$ seawater and f2 medium (Guillard \& Ryther 1962). Algae cultures were kept in a state of exponential growth with single cells dominating, but at high concentrations this was difficult to maintain. They were gently aerated continuously and stirred manually once to twice daily. To obtain the desired algal concentrations for the experiments, portions of the culture were diluted with filtered seawater.

Experimental setup. During the experimental runs, adult Calanus finmarchicus females were exposed to different concentrations of algae and nauplii. Concentrations of algae and abundance of nauplii were chosen to resemble natural conditions before and during the spring bloom. Chlorophyll a (chl a) concentrations ranged from 0.08 to $22.58 \mu \mathrm{g} \mathrm{l}^{-1}$. Abundances of nauplii were $0-3-6-9-5-20$ nauplii $\mathrm{l}^{-1}$. Each combination of initial carbon concentration and initial nauplii abundance was carried out in 2 to 6 replicates. Experimental units with no algae, no nauplii, and with and without female copepods served as controls. The units that contained only algae were used to correct for algal growth.

To start the experiment, 1 l Nalgene bottles were filled with algae suspension (or filtered seawater for the controls), then copepod nauplii (NI and NII) were added individually and, finally, 1 healthy looking adult female copepod with intact antennae was added. Incubating only 1 female per bottle allowed us to assess individual consumption rates. Bottles were kept on a slowly rotating plankton wheel (ca. $1 \mathrm{rpm}$ ) in the dark (or exposed to a maximum of $6 \mathrm{~h}$ light) for $24 \mathrm{~h}$.

The experiment was terminated by pouring the contents of the bottles through a $60 \mu \mathrm{m}$ sieve. To determine chl a concentrations, samples from the filtrate of each bottle were measured fluorometrically in triplicate using the method described by Holm-Hansen \& Riemann (1978) on a Turner designs model 10-AU fluorometer. In addition cell numbers were determined (Utermöhl 1931) from 42 samples in 2005. The remaining nauplii and adult females from the sieve were fixed in ethanol and counted under a stereoscopic microscope.

Conversion into carbon. Chl a concentrations and abundances of nauplii were converted into carbon values (C) to compare ingestion of both prey items. This was done by first converting the chl a values determined fluorometrically to cell numbers, which were then converted to carbon values. Cell numbers from the 42 samples in 2005 were plotted against corresponding chl a values; a regression line fitted by the least squares method then revealed a ratio of $1.5 \times$ 
$10^{5}$ cells $\mu g^{-1}$ chlorophyll $\left(\mathrm{r}^{2}=0.91\right)$ for the data ranging from 0 to $15 \mu \mathrm{g}$ chlorophyll $\mathrm{l}^{-1}$ (ratios $>15 \mu \mathrm{g}$ chlorophyll $1^{-1}$ were highly variable). A conversion factor of 305 pg C cell ${ }^{-1}$, which was determined by Reigstad et al. (2005) from the Thalassiosira weissflogii culture in 2004, was used to convert cell numbers into carbon content. The abundance of nauplii was converted into carbon using a value of $0.112 \mu \mathrm{g}$ C nauplii ${ }^{-1}$, which was the average carbon content of Calanus finmarchicus NII nauplii found by Hygum et al. (2000).

Data analysis. Clearance and ingestion rates were calculated as described by Frost (1972). The average concentration of algae and average abundance of nauplii throughout the $24 \mathrm{~h}$ experimental period were also calculated (Frost 1972) and grouped for statistical analyses. The resulting groups for algal concentrations were $0,20-50,50-200,200-500$ and $>500 \mathrm{mg} \mathrm{C} \mathrm{m}^{-3}$ and for nauplii abundances were $0,5-10$ and 10-20 nauplii $1^{-1}$ (Table 1). Four unbalanced univariate 2 -factorial ANOVAs were performed on clearance rates on algae, clearance rates on nauplii, ingestion rates on algae and on predation rates on nauplii, the 2 factors being average algal concentration (in carbon) and average nauplii abundance. Because of the unbalanced study design type III sum of squares were computed; these are based on unweighted marginal means and, therefore, are not influenced by the number of replicates in each cell. Clearance rates on algae and nauplii and ingestion rates on nauplii were square-root transformed before the analyses to approximate normal distribution and to increase homogeneity of variances. Ingestion rates on algae were 4 th root transformed for the same reason. The statistical package of Matlab (version 7.0, The Mathworks) was used for the ANOVAs.

Linear quantile regression analyses were carried out on ingestion rates on algae and predation rates on nauplii, the independent variables being average algal carbon and average naupliar carbon. Five extremely high values of ingestion rates on algae $(>500 \mu \mathrm{g} \mathrm{C}$ female $\mathrm{f}^{-1} \mathrm{~d}^{-1}$ ) and predation rates on nauplii (>1.5 $\mu \mathrm{g} \mathrm{C}$ female $^{-1} \mathrm{~d}^{-1}$ ) were excluded from these analyses. Quantile regression (Koenker \& Bassett 1978) fits a

Table 1. Number of replicates at each experimental treatment

\begin{tabular}{|lcccc|}
\hline \multirow{2}{*}{$\begin{array}{l}\text { Avg. algal conc. } \\
\left(\mu g \mathrm{C}^{-1}\right)\end{array}$} & \multicolumn{4}{c}{$\begin{array}{c}\text { Avg. nauplii abundance } \\
\left(\text { nauplii } 1^{-1}\right)\end{array}$} \\
& 0 & $0-5$ & $5-10$ & $10-20$ \\
\hline 0 & - & 10 & 5 & 11 \\
$0-20$ & 4 & 10 & 5 & 9 \\
$20-50$ & 5 & 9 & 5 & 5 \\
$50-200$ & 5 & 8 & 11 & 7 \\
$200-500$ & 3 & 8 & 5 & 7 \\
$>500$ & 4 & 9 & 2 & 3 \\
& & & & \\
\hline
\end{tabular}

given model to the data without assuming homogeneity of variances and is particularly useful when not all factors that might limit the response variable can be measured (Cade \& Noon 2003). In the case of this study, it was difficult to quantify egg production throughout the experiment; thus, some females might have preyed on produced eggs, while others, which did not produce eggs, might have been more limited by low abundances of algae and nauplii. We present the $50 \%$ quantiles fitted to the data in Fig. 5 (see 'Results'), but computed the $90 \%$ quantiles as well. All quantile regression analyses were performed using the quantreg package (available at: http://cran.rproject.org, section 'Packages') in $\mathrm{R}$ (available at: www.r-project.org).

Possible preference for one of the alternative prey was checked by plotting the proportion of naupliar carbon ingested $(P)$ versus proportion of naupliar carbon available $(F)$ and fitting the switching equation (Eq. 1) developed by Murdoch (1969) to these data. The parameter measuring preference therein is $C$.

$$
P=C F /(1-F+C F)
$$

\section{RESULTS}

At the end of the experiments a variable number of eggs was detected in some of the bottles, indicating that at least some Calanus finmarchicus females had another food source available in addition to algae and nauplii. In $8 \%$ of the bottles, food concentration was diminished to $<20 \%$ of the initial concentration. Clearance and ingestion rates in these bottles might have been higher than could be computed.

\section{Clearance and ingestion rates on algae}

Calanus finmarchicus females cleared the offered diatom Thalassiosira weissflogii at high rates and did not show saturation; clearance rates were equally high at concentrations $>500$ and $<20 \mathrm{mg}$ algal $\mathrm{C} \mathrm{m}^{-3}$ (Fig. 1). Clearance rates on algae were not significantly influenced by the abundance of nauplii (Fig. 2, Table 2). Clearance rates of individuals varied greatly: while average clearance rates were $221 \mathrm{ml}$ female $\mathrm{e}^{-1} \mathrm{~d}^{-1}$ some females cleared $>500 \mathrm{ml} \mathrm{d}^{-1}$.

Ingestion rates on Thalassiosira weissflogii increased significantly with increasing algal concentration (Figs. $1 \& 5$ a, Table 2), but were independent of ambient nauplii abundance (Figs. $2 \& 5$ a, Table 2). No interactive effect of the 2 prey items (nauplii and algae) on clearance or ingestion rates on $T$. weissflogii was detected (Table 2). 

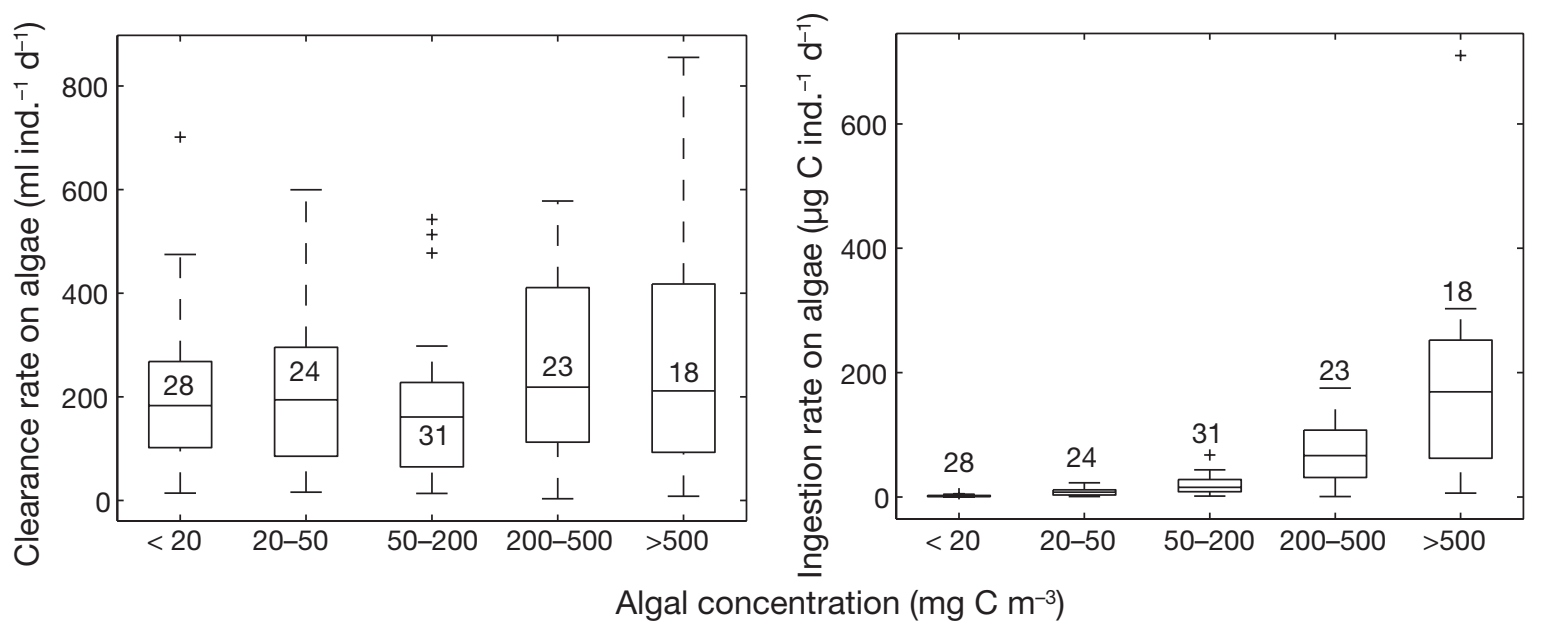

Fig. 1. Calanus finmarchicus. Clearance and ingestion rates of adult females on the diatom Thalassiosira weissflogii at different algal abundances, all different abundances of nauplii pooled. Number of replicates at a given algal concentration are shown in or above the boxes. Whiskers extend to 1.5 times the interquartile range of the sample; + : values outside this range

\section{Clearance and predation rates on nauplii}

Contrary to our hypothesis, algal concentration did not have a significant effect on the clearance or predation rates on nauplii, i.e. rates were equally high at all algal concentrations (Figs. 3 \& 5b, Table 2). Similarly, there was no interactive effect of algal concentration and nauplii abundance on clearance or predation rates on nauplii (Table 2), i.e. no switching was observed.

Clearance rates on nauplii of around $689 \mathrm{ml} \mathrm{female^{-1 }}$ $\mathrm{d}^{-1}$ were observed (Fig. 4). As seen with clearance rates on Thalassiosira weissflogii, clearance rates on nauplii varied greatly among individuals; 4 out of 151 females cleared $>2 \mathrm{l} \mathrm{d}^{-1}$. Clearance rates at high nauplii abundance (10 to 20 nauplii $\mathrm{l}^{-1}$ ) were significantly lower than at low ( 0 to 5 nauplii $1^{-1}$ ) and medium ( 5 to 10 nauplii $\mathrm{l}^{-1}$ ) abundance. With increasing abundance

Table 2. Results of the 4 univariate 2 -factorial ANOVAs. ${ }^{*}$ Significant at $\mathrm{p}<0.05$. ${ }^{* * *}$ Significant at $\mathrm{p}<0.001$

\begin{tabular}{|c|c|c|c|c|}
\hline & $\mathrm{Ms}_{\text {residual }}$ & Factor & $F$ & $\mathrm{p}$ \\
\hline Clearance rate on algae & 31.97 & $\begin{array}{l}\text { Algal conc. } \\
\text { Nauplii abundance } \\
\text { Interaction }\end{array}$ & $\begin{array}{l}F_{4,105}=0.79 \\
F_{3,105}=0.49 \\
F_{12,105}=1.16\end{array}$ & $\begin{array}{l}0.54 \\
0.69 \\
0.32\end{array}$ \\
\hline Ingestion rate on algae & 0.26 & $\begin{array}{l}\text { Algal conc. } \\
\text { Nauplii abundance } \\
\text { Interaction }\end{array}$ & $\begin{array}{l}F_{4,105}=58.95 \\
F_{3,105}=0.92 \\
F_{12,105}=1.08\end{array}$ & $\begin{array}{c}<0.001^{* * *} \\
0.43 \\
0.38\end{array}$ \\
\hline Clearance rate on nauplii & 163.58 & $\begin{array}{l}\text { Algal conc. } \\
\text { Nauplii abundance } \\
\text { Interaction }\end{array}$ & $\begin{array}{l}F_{5,109}=2.88 \\
F_{2,109}=5.21 \\
F_{10,109}=1.64\end{array}$ & $\begin{array}{c}0.02^{*} \\
0.01^{*} \\
0.11\end{array}$ \\
\hline Predation rate on nauplii & 0.07 & $\begin{array}{l}\text { Algal conc. } \\
\text { Nauplii abundance } \\
\text { Interaction }\end{array}$ & $\begin{array}{l}F_{5,109}=1.71 \\
F_{2,109}=16.97 \\
F_{10,109}=0.56\end{array}$ & $\begin{array}{c}0.14 \\
<0.001^{* * *} \\
0.84\end{array}$ \\
\hline
\end{tabular}

of nauplii, predation rates on nauplii increased linearly and significantly up to 10 nauplii, or $1.2 \mu \mathrm{g} \mathrm{C}$ female $\mathrm{e}^{-1}$ $\mathrm{d}^{-1}$ (Figs. $4 \& 5 \mathrm{~b}$, Table 2). They did not reach saturation at 20 nauplii $\mathrm{l}^{-1}$ (Figs. 4 \& 5b). The $90 \%$ quantile regression (not shown) had a much steeper slope than the $50 \%$ quantile (Fig. 5) and the predation rate on nauplii was then, at $2 \mathrm{mg}$ naupliar $\mathrm{C} \mathrm{m}^{-3}, 2.5 \mu \mathrm{g} \mathrm{C}$ ind. ${ }^{-1} \mathrm{~d}^{-1}$, showing that $10 \%$ of the females preyed at very high rates on nauplii.

\section{Prey preference}

Calanus finmarchicus females constantly ingested naupliar carbon at a higher proportion than was available (Fig. 6). The preference parameter obtained from the fitted switching equation was 2.69; however, the fit of the equation was poor $\left(\mathrm{r}^{2}=\right.$ 0.37). Due to few values at high proportions of naupliar carbon, the uncertainty associated with the form of the curve at values $>0.30$ is large.

\section{DISCUSSION}

The experiments to test for cannibalism by adult Calanus finmarchicus females on nauplii were carried out under conditions resembling environmental conditions during spring as far as possible. Both prey items, algae and nauplii, were offered in abun- 


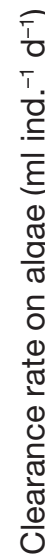

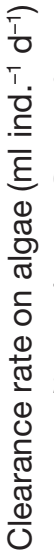
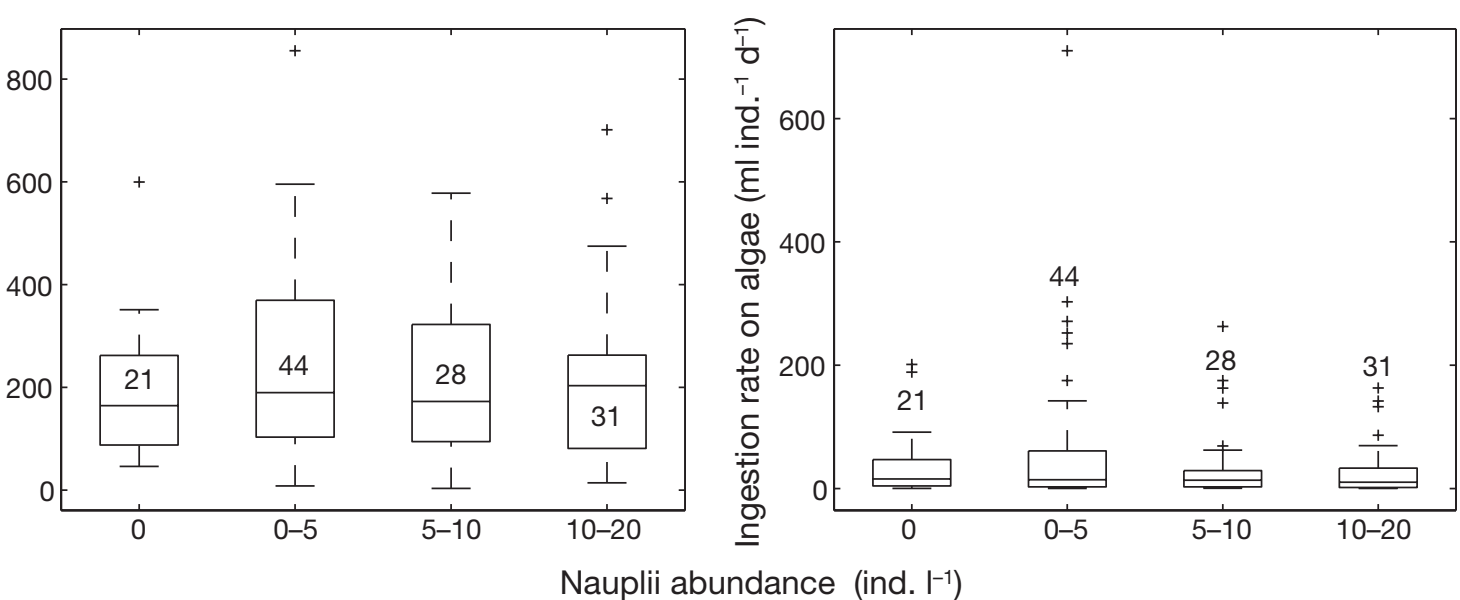

Fig. 2. Calanus finmarchicus. Clearance and ingestion rates of adult females on the diatom Thalassiosira weissflogii at different abundances of NI and NII nauplii, all different $T$. weissflogii concentrations pooled. Number of replicates at the different nauplii abundances are shown in or above the boxes. Whiskers extend to 1.5 times the interquartile range of the sample; +: values outside this range

dances usually found before and during the spring bloom (Hegseth et al. 1995, Eilertsen \& Wyatt 2000, Hirche et al. 2001). The high variability in clearance and ingestion rates at high algal concentrations might be explained partly by the formation of aggregates that caused non-homogeneity in chl a measurements. Food concentration changed throughout the experiment, and at low food concentrations larger experimental bottles or a shorter experimental period may have been more appropriate. We therefore computed and presented rates versus average food concentration during the experiment instead of initial food concentration. Only active females were selected for the experiments, but we did not check their gonad status. Thus, it is likely that time of individual spawning varied and that females ingested a variable amount of eggs during the experiment in addition to algae and nauplii. This may have contributed to the high individual variability observed in clearance rates on algae and nauplii. Indeed, quantile regression revealed that the slope of the $90 \%$ quantiles that were fitted to ingestion rates on algae and to predation rates on nauplii were much steeper than that of the $50 \%$ quantiles, indicating that in the absence of a factor like predation on eggs ingestion of both prey items may have been even higher.
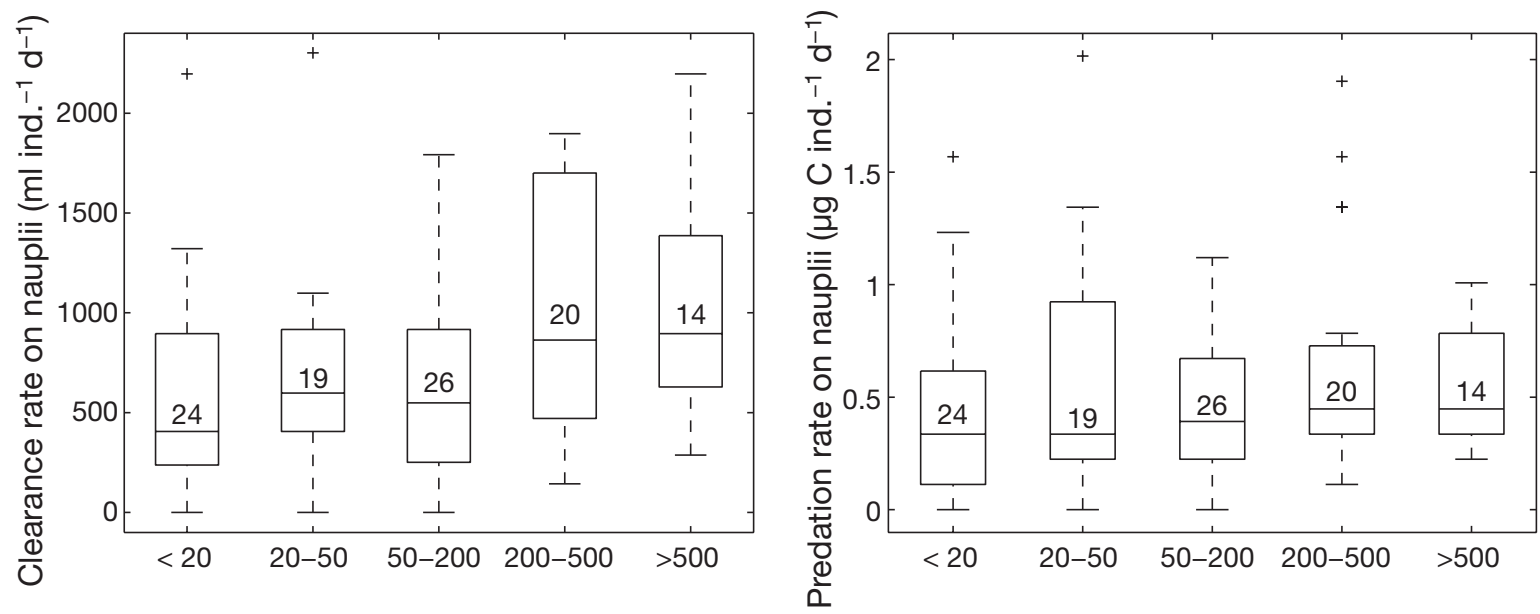

Algal concentration ( $\mathrm{mg} \mathrm{C} \mathrm{m}^{-3}$ )

Fig. 3. Calanus finmarchicus. Clearance and predation rates of adult females on NI and NII nauplii at different concentrations of Thalassiosira weissflogii, all different nauplii abundances pooled. Number of replicates at a given algal concentration are shown in the boxes. Whiskers extend to 1.5 times the interquartile range of the sample; +: values outside this range 

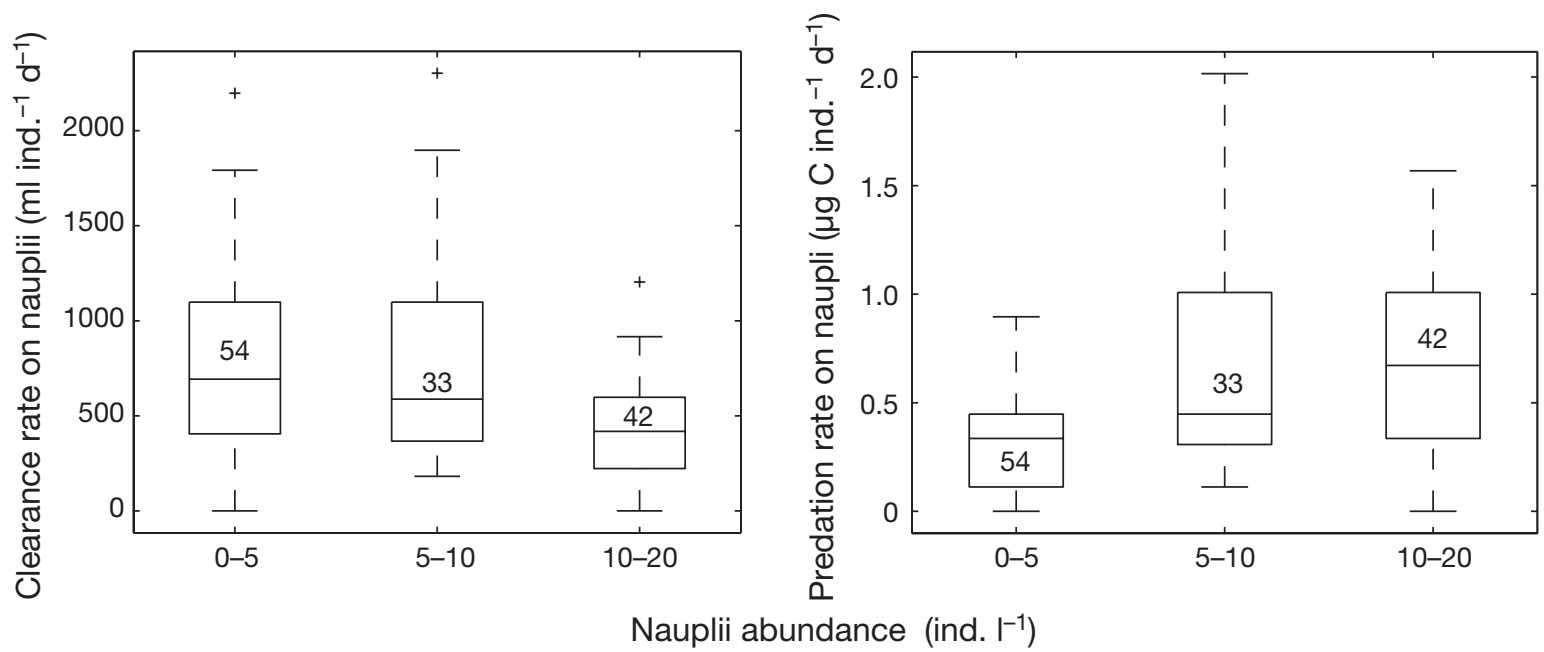

Fig. 4. Calanus finmarchicus. Clearance and predation rates of adult females on NI and NII nauplii at different abundances of nauplii, all different Thalassiosira weissflogii concentrations pooled. Number of replicates at the different nauplii abundances are shown in the boxes. Whiskers extend to 1.5 times the interquartile range of the sample; + : values outside this range
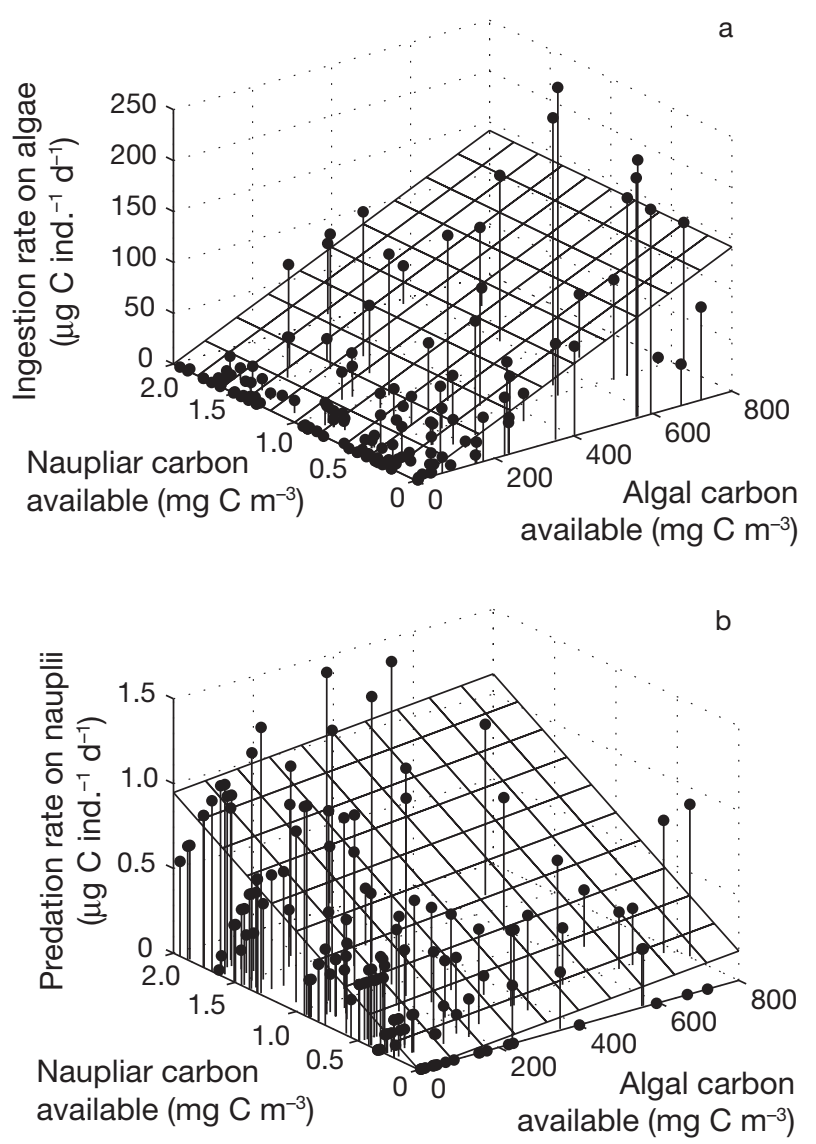

Fig. 5. Calanus finmarchicus. Ingestion and predation rates of adult females on (a) algae and (b) nauplii in relation to the availability of both prey items. Grids show the $50 \%$ quantile and were fitted to the data by quantile regression analysis, see 'Materials and methods' for description
The clearance and ingestion rates on Thalassiosira weissflogii were relatively high, but in the range of previously observed rates of late Calanus finmarchicus stages feeding on diatoms or on the natural algae community (Cushing \& Vucetic 1963, Barthel 1988, MeyerHarms et al. 1999, Meyer et al. 2002). Clearance rates were also high at algal concentrations below $20 \mathrm{mg} \mathrm{C}$ $\mathrm{m}^{-3}$; thus no, or only a very low, threshold concentration seems to be associated with the filtering of T. weissflogii cells. Contrary to most publications (e.g. Frost 1972), copepod females in our study did not show saturation even at high algal concentrations. This might be explained by the variability in chl a measurements at high algal concentrations. Another explanation might be that the high variability in clearance rates of individuals masked a functional response curve.

The great span in behaviour of females was also obvious in clearance and predation rates on nauplii. Clearance rates on nauplii were high, with some females clearing up to $2 \mathrm{l} \mathrm{d}^{-1}$, which is similar to clearance rates of the predatory copepod Euchaeta elongata on Calanus pacificus NV and NVI nauplii (1.5 l female ${ }^{-1} \mathrm{~d}^{-1}$, Greene \& Landry 1985). On average, however, C. finmarchicus females cleared $689 \mathrm{ml} \mathrm{d}^{-1}$, which is higher than clearance rates of the omnivorous copepod Metridia lucens on C. finmarchicus NIII nauplii (440 ml female $\mathrm{f}^{-1} \mathrm{~d}^{-1}$, Sell et al. 2001) and also considerably higher than clearance rates of the sibling species C. helgolandicus on their own nauplii (141 to $196 \mathrm{ml}$ female $\mathrm{e}^{-1} \mathrm{~d}^{-1}$, Bonnet et al. 2004). In contrast, clearance rates of $C$. finmarchicus correspond to clearance rates of C. pacificus on their own NV-NVI nauplii (ca. $669 \mathrm{ml}$ female ${ }^{-1} \mathrm{~d}^{-1}$, Landry 1980). Predation rates of female $C$. finmarchicus on their nauplii were, at 


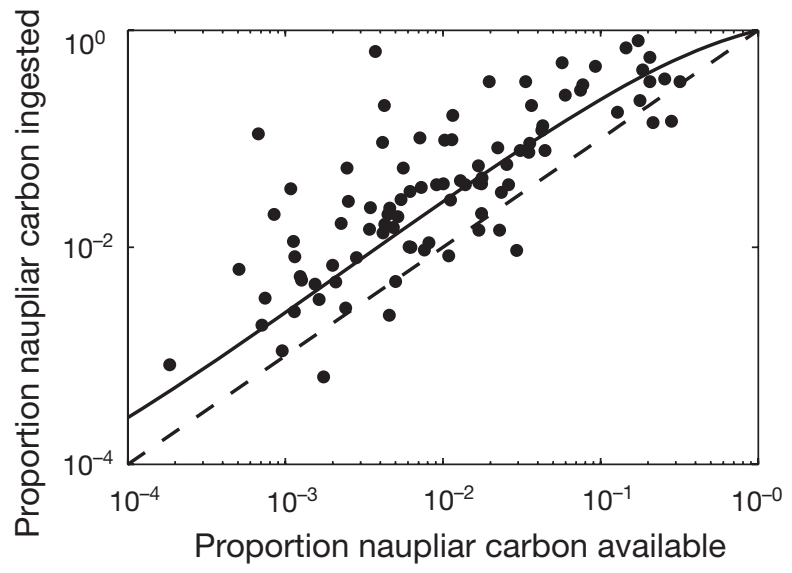

Fig. 6. Calanus finmarchicus. Proportion of naupliar carbon ingested by adult females in relation to the proportion available. Dashed line shows expected values at no preference for either prey item and with no switching. The solid line $\left(y=2.69 x /(1-x+2.69 x), r^{2}=0.37\right)$ was fitted to the data using the switching equation developed by Murdoch (1969)

equal initial prey abundance, higher than those of the 2 closely related copepods $C$. helgolandicus and $C$. pacificus on their nauplii (Fig. 7). They were also higher than predation rates of $M$. lucens on $C$. finmarchicus NIII nauplii, but lower than predation rates of E. elongata on C. pacificus nauplii (Fig. 7). Of the 3 Calanus species, only predation rates of $C$. helgolandicus reach saturation at abundances of nauplii that are likely to occur naturally (Bonnet et al. 2004). Though clearance rates of $C$. finmarchicus decreased slightly at high nauplii abundances, predation rates increased linearly (at least up to 20 nauplii $1^{-1}$ ) and predation rates of $C$. pacificus do not reach saturation even at extremely high nauplii abundances of close to 200 nauplii $\mathrm{l}^{-1}$ (Landry 1981).

When nauplii abundances are very high and concentrations of algae are very low, i.e. when $>80 \%$ of the available carbon consists of naupliar C, Calanus pacificus switches its prey preference from algae to nauplii (Landry 1981). Switching behaviour related to the abundance of alternative prey is also known from other calanoid copepods such as Acartia tonsa (Kiørboe et al. 1996). We did not observe a switch from herbivory to carnivory in our experiments, however. Since one young $C$. finmarchicus nauplius contains only ca. 0.112 ug C (Hygum et al. 2000), naupliar carbon never amounted to $>35 \%$ of the available carbon in our experiments, even at low concentrations of algae $\left(<20 \mu \mathrm{g} \mathrm{C}^{-1}\right)$ and high abundances of nauplii (20 nauplii $\mathrm{l}^{-1}$ ). Nevertheless $C$. finmarchicus females did cannibalise on nauplii at high rates even when algal food supply was sufficient. To feed on small particles such as Thalassiosira weissflogii cells, C. finmarchicus sets up a filter current, while large particles like nauplii are most likely caught individually by a forward sweep of the spread maxillae (Gauld 1966). Young Calanus sp. nauplii (NI and NII) display a sink-jump behaviour, i.e. they sink and only occasionally jump to interrupt sinking (Titelman \& Kiørboe 2003). They are thus likely to be trapped in the feeding current and only caught when they approach the mouth parts of adults. The energetic cost associated with cannibalism on young nauplii is thus probably low, which might explain the continued cannibalism at high algal concentration. The observed preference for nauplii suggests, however, that adult $C$. finmarchicus females actively hunt for the young nauplii. Older Calanus spp. nauplii swim slowly more or less continuously (Landry 1978, Titelman \& Kiørboe 2003). C. pacificus prefers older over younger nauplii, though predation on larger nauplii is likely to be associated with higher energetic cost, since moving particles are sensed remotely by means of the first antennae (Landry 1980) and first have to be approached by the adults before being captured. Our study was not set up to detect cannibalism on older nauplii and therefore we could not test if switching to pure herbivory at high algal concentrations occurs when older nauplii are the alternative prey.

In the field, a situation where naupliar carbon levels are dominant over algal carbon is probably rare. When females gather in surface waters and start reproducing during the algal pre-bloom period, algal concentrations are low but so are nauplii abundances. Depending on the quality of algal food during the pre-bloom, and also on the availability of microzooplankton, the

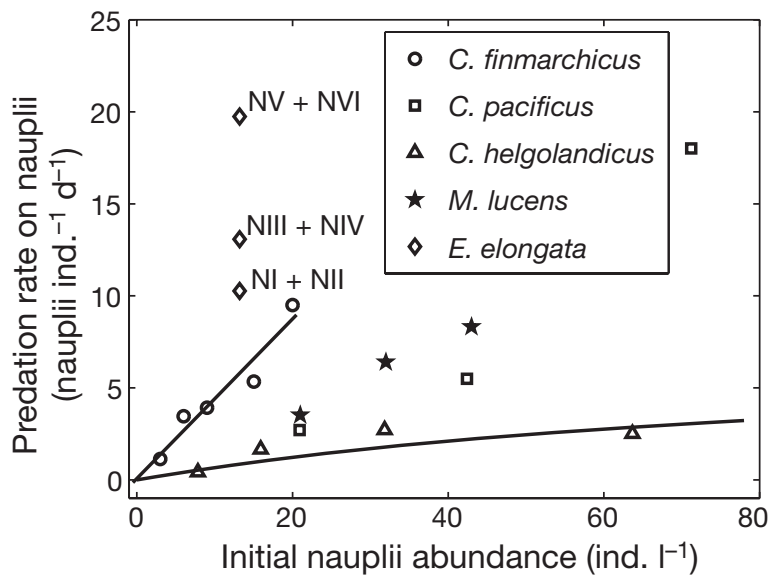

Fig. 7. Predation rates of female calanoid copepods on Calanus spp. nauplii. C. finmarchicus cannibalising on NI + NII nauplii at $6^{\circ} \mathrm{C}$, this study $\left(y=0.4338 x+0.0716, r^{2}=0.93\right)$. C. pacificus cannibalising on NIV nauplii at $15^{\circ} \mathrm{C}$, Landry (1981). C. helgolandicus cannibalising on NII/NIII nauplii at 13 to $15^{\circ} \mathrm{C}$, Bonnet et al. (2004), their regression from their Fig. 1B. Metridia lucens preying on C. finmarchicus NIII naupliii at $6^{\circ} \mathrm{C}$, Sell et al. (2001). Euchaeta elongata preying on different stages of $C$. pacificus nauplii at $8^{\circ} \mathrm{C}$, Greene \& Landry (1985) 
benefit of cannibalism for females is probably simply an easily accessible nutritional supplement. During the algal post-bloom, when algae biomass again declines, most nauplii will have developed into copepodites. Therefore, in spite of high clearance rates on nauplii, female Calanus finmarchicus are likely to gain most of their energy from algal food. In the southern Norwegian Sea, abundance of females reached up to 290 ind. $\mathrm{m}^{-3}$ in surface waters during the pre-bloom in 1997 (Niehoff et al. 1999). Applying a clearance rate of 689 $\mathrm{ml}$ female ${ }^{-1} \mathrm{~d}^{-1}$, the total clearance rate on nauplii by the population of females was $\sim 200 \mathrm{l} \mathrm{m}^{-3} \mathrm{~d}^{-1}$, i.e. adult C. finmarchicus may cannibalise up to $20 \%$ of the NI/NII population per day. These values are extreme, but give an indication of the maximal cannibalistic impact of $C$. finmarchicus females on nauplii during the pre-bloom period. Stage V copepodites also cannibalised nauplii (S. Basedow pers. obs.) and may additionally contribute to the predation pressure on young nauplii. The impact of cannibalism will also depend on the degree of vertical overlap between nauplii and $\mathrm{CV}-\mathrm{CVI}$ copepodites. Stage-specific diel vertical migration (DVM) might separate developmental stages vertically and mitigate the effect of cannibalism. While young Calanus spp. nauplii do not perform DVM (Nicholls 1933, Huntley \& Brooks 1982, Uye et al. 1990), females show a high flexibility in DVM amplitude (Irigoien et al. 2004) in relation to food (Huntley \& Brooks 1982) and predators (Bollens \& Frost 1989). During periods of food scarcity, however, DVM is considered to be a non-rewarding strategy even at high predation risk (Manteifel 1959, Fiksen \& Giske 1995). Then Calanus spp. females have been observed to cease migrating and locate at the depth of maximum food (Huntley \& Brooks 1982). Nauplii and females are thus likely to overlap vertically, but little is known about small-scale segregation of Calanus spp. developmental stages during the pre-bloom. As long as abundance of nauplii is small and abundance of females is large, cannibalism may severely impact the population dynamics of $C$. finmarchicus and may prevent recruitment to the G1 population. The abundance of females decreases during the algal bloom and egg production rates increase with increasing algal concentration (Diel \& Tande 1992, Plourde \& Runge 1993, Niehoff et al. 1999). Thus the cannibalistic impact of females on the nauplii population will decrease over time during the start of the spring bloom, allowing nauplii to recruit simultaneously with the developing bloom. The pattern of a near-synchronous peak of high abundance of phytoplankton and CI-CIII copepodites, which was observed by Ohman \& Hirche (2001) in the southern oceanic Norwegian Sea, can thus be explained by cannibalism. According to our experiments, the decrease in cannibalism on nauplii at higher algal concentrations is not due to lower per capita cannibalism but rather is linked to the lower abundance of females and the increase in per capita egg production.

Acknowledgements. We thank the crew on board RV 'Hyas' for their friendly assistance during collection of the copepods. We also thank C. Wexels Riser and M. Reigstad for the Thalassiosira weissflogii cultures. The helpful suggestions of 2 anonymous referees, which improved the manuscript, are acknowledged.

\section{LITERATURE CITED}

Barthel KG (1988) Feeding of three Calanus species on different phytoplankton assemblages in the Greenland Sea. Meeresforsch 32:92-106

Bollens SM, Frost BW (1989) Predator-induced diel vertical migration in a planktonic copepod. J Plankton Res 11:1047-1065

Bonnet D, Titelmann J, Harris R (2004) Calanus the cannibal. J Plankton Res 26:937-948

Cade BS, Noon BR (2003) A gentle introduction to quantile regression for ecologists. Front Ecol Environ 1:412-420

Cushing DH, Vucetic T (1963) Studies on a Calanus patch. III. The quantity of food eaten by Calanus finmarchicus. J Mar Biol Assoc UK 43:349-371

Dale T, Rey F, Heimdal BR (1999) Seasonal development of phytoplankton at a high latitude oceanic site. Sarsia 84 : 419-435

Dalpadado P, Ellertsen B, Melle W, Dommasnes A (2000) Food and feeding conditions of Norwegian spring-spawning herring (Clupea harengus) through its feeding migrations. ICES J Mar Sci 57:843-857

Diel S, Tande K (1992) Does the spawning of Calanus finmarchicus in high latitudes follow a reproducible pattern? Mar Biol 113:21-31

Eiane K, Aksnes DL, Ohman MD, Wood S, Martinussen MB (2002) Stage-specific mortality of Calanus spp. under different predation regimes. Limnol Oceanogr 47:636-645

Eilertsen HC, Wyatt T (2000) Phytoplankton models and life history strategies. S Afr J Mar Sci/S-Afr Tydskr Seewet 22:323-338

Fiksen O, Giske J (1995) Vertical distribution and population dynamics of copepods by dynamic optimization. ICES J Mar Sci 52:483-503

Fox LR (1975) Cannibalism in natural populations. Annu Rev Ecol Syst 6:87-106

Frost BW (1972) Effects of size and concentration of food particles on feeding behavior of the marine planktonic copepod Calanus pacificus. Limnol Oceanogr 17:805-815

Gaard E, Reinert J (2002) Pelagic cod and haddock juveniles on the Faroe plateau: distribution, diets and feeding habitats, 1994-1996. Sarsia 87:193-206

Gauld DT (1966) The swimming and feeding of planktonic copepods. In: Marshall SM, Orr AP, Barnes H (eds) Some contemporary studies in marine science. Allen \& Unwin, London, p 313-334

Gislason A, Astthorsson AS (2002) The food of Norwegian spring-spawning herring in the western Norwegian Sea in relation to the annual cycle of zooplankton. Sarsia 87: 236-247

Greene CH, Landry MR (1985) Patterns of prey selection in the cruising calanoid predator Euchaeta elongata. Ecology 66:1408-1416 
Guillard RRL, Ryther JH (1962) Studies on marine planktonic diatoms Cyclotella nana (Hustedt) and Detonula confervacea (Cleve) Gran. Can J Microbiol 8:229-239

Harvey HW (1936) Annual variation of planktonic vegetation, 1933. J Mar Biol Assoc UK 19:775-792

Hegseth EN, Svendsen H, von Quillfeldt CH (1995) Phytoplankton in fjords and coastal waters of northern Norway: environmental conditions and dynamics of the spring bloom. In: Skjoldal HR, Hopkins C, Erikstad KE, Leinaas HP (eds) Ecology of fjords and coastal waters. Elsevier Science, Amsterdam, p 45-72

Hirche HJ, Brey T, Niehoff B (2001) A high-frequency time series at Ocean Weather Ship Station M (Norwegian Sea): population dynamics of Calanus finmarchicus. Mar Ecol Prog Ser 219:205-219

Holm-Hansen O, Riemann B (1978) Chlorophyll a determination: improvements in methodology. Oikos 30:438-447

Huntley M, Brooks ER (1982) Effects of age and food availability on diel vertical migration of Calanus pacificus. Mar Biol 71:23-31

Hygum BH, Rey C, Hansen BW (2000) Growth and development rates of Calanus finmarchicus nauplii during a diatom spring bloom. Mar Biol 136:1075-1085

Irigoien X, Titelman J, Harris RP, Harbour D, Castellani C (2003) Feeding of Calanus finmarchicus nauplii in the Irminger Sea. Mar Ecol Prog Ser 262:193-200

Irigoien X, Conway DVP, Harris RP (2004) Flexible diel vertical migration behaviour of zooplankton in the Irish Sea. Mar Ecol Prog Ser 267:85-97

Kang HK, Poulet SA (2000) Reproductive success in Calanus helgolandicus

as a function of diet and egg cannibalism. Mar Ecol Prog Ser 201:241-250

Kiørboe T, Saiz E, Viitasalo M (1996) Prey switching behaviour in the planktonic copepod Acartia tonsa. Mar Ecol Prog Ser 143:65-7

Koenker R (2006) Quantreg: quantile regression. R package version 3.85. Available at: www.R-project.org

Koenker R, Bassett G (1978) Regression quantiles. Econometrica $46: 33-50$

Landry MR (1978) Population dynamics and production of a planktonic marine copepod Acartia clausii in a small temperate lagoon on San Juan Island, Washington. Int Rev Ges Hydrobiol 63:77-119

Landry MR (1980) Detection of prey by Calanus pacificusimplications of the 1st antennae. Limnol Oceanogr 25: 545-549

Landry MR (1981) Switching between herbivory and carnivory by the planktonic marine copepod Calanus pacificus. Mar Biol 65:77-82

Levinsen H, Turner JT, Nielsen TG, Hansen BW (2000) On the trophic coupling between protists and copepods in arctic marine ecosystems Mar Ecol Prog Ser 204:65-77

Longhurst AR (1976) Interactions between zooplankton and phytoplankton profiles in eastern tropical Pacific Ocean. Deep-Sea Res 23:729-754

Lorenz K (1966) On aggression. Bantam Books, New York Manteifel BP (1959) Vertical migration of sea organisms. Tr Inst Morfol Zhivotn Akad Nauk SSSR 13:62-117 (in Russian)

Marshall SM, Orr AP (1955) On the biology of Calanus finmarchicus. 8. Food uptake, assimilation and excretion in

Editorial responsibility: Otto Kinne (Editor-in-Chief), Oldendorf/Luhe, Germany adult and stage V Calanus. J Mar Biol Assoc UK 34: 495-529

Meyer B, Irigoien X, Graeve M, Head RN, Harris RP (2002) Feeding rates and selectivity among nauplii, copepodites and adult females of Calanus finmarchicus and Calanus helgolandicus. Helgol Mar Res 56:169-176

Meyer-Harms B, Irigoien X, Head R, Harris R (1999) Selective feeding on natural phytoplankton by Calanus finmarchicus before, during, and after the 1997 springbloom in the Norwegian Sea. Limnol Oceanogr 44: 154-165

Murdoch WW (1969) Switching in general predators: experiments on predator specificity and stability of prey populations. Ecol Monogr 39:335-354

Nicholls AG (1933) On the biology of Calanus finmarchicus. III. Vertical distribution and diurnal migration in the Clyde Sea-area. J Mar Biol Assoc UK 19:139-164

Niehoff B, Klenke U, Hirche HJ, Irigoien X, Head R, Harris R (1999) A high frequency time series at Weathership $M$, Norwegian Sea, during the 1997 spring bloom: the reproductive biology of Calanus finmarchicus. Mar Ecol Prog Ser 176:81-92

Ohman MD, Hirche HJ (2001) Density-dependent mortality in an oceanic copepod population. Nature 412:638-641

Ohman MD, Runge JA (1994) Sustained fecundity when phytoplankton resources are in short supply - omnivory by Calanus finmarchicus in the gulf of St Lawrence. Limnol Oceanogr 39:21-36

Planque B, Batten SD (2000) Calanus finmarchicus in the North Atlantic: the year of Calanus in the context of interdecadal change. ICES J Mar Sci 57:1528-1535

Plourde S, Runge JA (1993) Reproduction of the planktonic copepod Calanus finmarchicus in the Lower St. Lawrence Estuary: relation to the cycle of phytoplankton production and evidence for a Calanus pump. Mar Ecol Prog Ser 102: 217-227

Polis GA (1981) The evolution and dynamics of intraspecific predation. Annu Rev Ecol Syst 12:225-251

R Development Core Team (2005) R: a language and environment for statistical computing. R Foundation for Statistical Computing, Vienna. Available at: www.Rproject.org

Reigstad M, Wexels Riser C, Svensen C (2005) Fate of copepod faecal pellets and the role of Oithona spp. Mar Ecol Prog Ser 304:265-270

Sell AF, van Keuren D, Madin LP (2001) Predation by omnivorous copepods on early developmental stages of Calanus finmarchicus and Pseudocalanus spp. Limnol Oceanogr 46:953-959

Titelman J, Kiørboe T (2003) Motility of copepod nauplii and implications for food encounter. Mar Ecol Prog Ser 247: 123-135

Utermöhl H (1931) Neue Wege in der quantitativen Erfassung des Planktons. (Mit besonderer Berücksichtigung des Ultraplanktons). Verh Int Verein Theor Angew Limnol 5: 567-596

Uye S, Huang C, Onbe T (1990) Ontogenic diel vertical migration of the planktonic copepod Calanus sinicus in the Inland Sea of Japan. Mar Biol 104:389-396

Wilson EO (1975) Sociobiology: the new synthesis. Harvard University Press, Cambridge, MA

Submitted: February 1, 2006; Accepted: April 18, 2006

Proofs received from author(s): October 9, 2006 